\title{
PLAINTIFF CULPABILITY AND THE NEW ZEALAND TORT OF INVASION OF PRIVACY
}

\author{
Lisa Tat ${ }^{*}$
}

The tort of invasion of privacy is still a relatively new cause of action in New Zealand, which means that there are many novel issues that the courts will face in future cases that require consideration. One such issue is that of plaintiff culpability. While the concept is not entirely novel, it is yet to be examined in depth. The concept was discussed in the High Court decision of Andrews v TVNZ and the case forms the basis of analysis in this article. Drawing on case law from New Zealand and the United Kingdom the article examines the concept of plaintiff culpability and determines what it means and how it should be considered in an invasion of privacy action. The facts of Andrews $\mathrm{v}$ TVNZ are revisited to illustrate how the results of the analysis might be applied in future cases.

\section{INTRODUCTION}

Privacy is an elusive concept; there is no one definition that fully encapsulates what is meant by the term. ${ }^{1}$ Broadly speaking, privacy is a person's concern over their accessibility to others. ${ }^{2}$ This accessibility could be in the form of knowledge or information about an individual, physical access, or the extent to which a person is the subject of others' attention. ${ }^{3}$ In other words, the meaning of privacy takes its form according to the context in which its protection is sought.

* Submitted as part of the LLB(Hons) programme at Victoria University of Wellington.

1 See for example, Nicole Moreham "Privacy in the Common Law" (2005) 121 LQR 628, 636-643; Geoffrey Palmer "Privacy and the Law" [1975] NZLJ 747; William Prosser "Privacy" (1960) 48 Cal L Rev 383; Raymond Wacks (ed) Privacy (Dartmouth Publishing Company Limited, Hants, England, 1993) Volume I Part I.

2 See for example, Ruth Gavison "Privacy and the Limits of the Law" (1980) 89 Yale LJ 421, 423; Moreham, ibid, 639; Michael Tugendhat QC and Iain Christie (eds) The Law of Privacy and the Media (Oxford University Press, Oxford, 2002) xi.

3 Gavison, ibid. 
It was not until the Court of Appeal's decision in Hosking $v$ Runting 4 that a tort of invasion of privacy was confirmed as existing in New Zealand. The New Zealand tort is concerned with wrongful publicity given to private lives. ${ }^{5}$ The two fundamental requirements for a claim of an invasion of privacy are: ${ }^{6}$

(1) The existence of facts ${ }^{7}$ in respect of which there is a reasonable expectation of privacy; and

(2) Publicity given to those private facts that would be considered highly offensive to an objective reasonable person.

These two requirements provide the basis of the tort, but as the majority in Hosking $v$ Runting recognised, the scope of the tort must be developed incrementally by the courts in future cases. ${ }^{8} \mathrm{An}$ issue that is ripe for development is that of plaintiff culpability; that is, what is the relevance of a plaintiff who has done something "bad" and wants to prevent its publication? There have been several New Zealand invasion of privacy cases where the plaintiff has behaved "badly", but it has not been clear how, if at all, the courts have taken that fact into account.

The aim of this article is to determine what plaintiff culpability means and how it should impact on the New Zealand tort of invasion of privacy. The recent High Court decision of Andrews v TVNZ will form the basis of analysis in this article, as it is the only case thus far to have expressly discussed the issue of plaintiff culpability. After a brief introduction to the case, the next part of the article looks at what plaintiff culpability means in the context of an invasion of privacy claim. Using that definition, the article then looks at why culpability should be taken into account under the tort of invasion of privacy, and then how it should be considered under the tort. Lastly, Andrews $v$ TVNZ will be revisited to consider how plaintiff culpability could have affected the outcome.

This article reaches the following conclusions. First, plaintiff culpability entails behaviour where the plaintiff could be described as having been, at least partly, responsible for the publicity

$4 \quad$ Hosking v Runting [2005] 1 NZLR 1 (CA).

5 Ibid, para 125 Gault P and Blanchard J. See generally, Prosser, above n 1; Samuel Warren and Louis Brandeis "The Right to Privacy" (1890) 4 Harv L Rev 193.

$6 \quad$ Hosking $v$ Runting, ibid, para 117 Gault P and Blanchard J. These requirements were reaffirmed in Rogers $v$ Television New Zealand [2007] 1 NZLR 156 (CA), which has subsequently been upheld by the Supreme Court in Rogers $v$ Television New Zealand Limited [2007] NZSC 91.

7 Tipping $\mathrm{J}$ used the expression "information or material" instead of the term "facts" in Hosking $v$ Runting, ibid, para 257. This distinction was noted by Allan J in Andrews $v$ TVNZ (15 December 2006) HC AK CIV 2004-404-3536, para 26, and his Honour appeared to prefer the use of "information or material" to describe what was involved in the case, rather than the term "facts". This article will use the terms interchangeably. For information about the distinction, see Moreham, above n 1.

8 Hosking v Runting, ibid, para 117 Gault P and Blanchard J. 
complained of. Second, culpability in itself is not determinative of an invasion of privacy claim. Culpability is, however, a factor to consider under the defence of legitimate public interest. Finally, the plaintiffs' culpability should have been considered under the public interest defence in Andrews $v$ TVNZ. Even though the culpability would not have affected the outcome, it is important to treat it as an independent consideration to set a precedent that can be applied in future invasion of privacy claims.

\section{ANDREWS V TVNZ}

\section{A Facts}

The plaintiffs were husband and wife. One night after attending a party and consuming an unspecified quantity of alcohol they had a serious road accident as they drove home. While never explicitly stated, it was implied that the accident was caused by the driver's excess blood alcohol level. The plaintiffs were trapped in the vehicle and it was necessary to use heavy equipment to free them. It transpired that a television crew was filming the rescue mission for a programme that documented the lives of fire fighters. The plaintiffs were completely unaware that the filming had taken place; they found out about it only when the footage was aired during an episode of the programme on TV One.

A considerable amount of the footage was devoted to depicting the plaintiffs while they were trapped in the car, primarily in respect of their interaction with rescue staff. Included in the footage aired were the intimate conversations shared between the husband and wife where the wife was rather distressed. There was, however, no reference to the cause of the accident or the fact that each plaintiff was significantly over the legal blood alcohol limit. Neither plaintiff was charged with driving over the limit, because the police could not ascertain who was driving the vehicle. The plaintiffs sued Television New Zealand for an invasion of privacy in respect of the conversations and scenes depicted in the programme.

\section{B The Judgment of Allan $J$}

Allan $\mathrm{J}$ held that the broadcast did not amount to an invasion of the Andrews' privacy, despite their successful argument that they were entitled to a reasonable expectation of privacy in respect of their conversations. Allan J found that due to the intimate nature of the conversations, the Andrews were entitled to expect that the conversations would not be given further publicity. ${ }^{9}$ However, the Andrews failed the "highly offensive" test. The judge ruled that a reasonable person in the shoes of the plaintiffs would not have found the broadcast of the conversations during the television programme to be highly offensive. ${ }^{10}$ Further, had it been necessary, Allan $\mathrm{J}$ would have upheld a

9 Ibid, para 65 Allan J.

10 Ibid, para 71 Allan J. 
defence of legitimate public concern in including the footage of the conversations in the programme. ${ }^{11}$

A notable omission from Allan J's judgment is that his Honour did not discuss the relevance of the Andrews' "bad" behaviour. That is, he did not discuss whether the fact that the driver of the vehicle was drunk at the time of the accident was a relevant consideration under the tort. The omission is curious because his Honour had earlier in his decision discussed the potential relevance of plaintiff culpability under the tort of invasion of privacy. The facts in Andrews $v$ TVNZ provided a good opportunity to test the new principle, yet the case was decided without explicit reference to the relevance of plaintiff culpability. Nevertheless, Allan J's discussion about plaintiff culpability provides a basis for analysis of the issue.

\section{PLAINTIFF CULPABILITY}

On the issue of plaintiff culpability, his Honour said that: ${ }^{12}$

On occasion, it may be appropriate in assessing the reasonableness of an expectation of privacy, to take into account the culpability or blameworthiness of the plaintiff.

$\ldots$

It is difficult, and indeed undesirable, to lay down any general principle governing the extent to which personal culpability might impinge upon reasonable expectations of privacy .... The character and seriousness of blameworthy conduct, or iniquity, will vary significantly from case to case. The effect of such conduct on a reasonable expectation of privacy will therefore also vary.

I accept, however, that an expectation of privacy, otherwise reasonable, may in certain circumstances be lost by reason of culpability on the part of the plaintiff. It is to be observed that the same consideration might well arise in a given case in the course of an assessment of whether publication of private facts is highly offensive, and further, in relation to the defence of legitimate public concern.

At first instance, this passage appears to provide useful guidance about plaintiff culpability. However, upon a closer inspection, the passage is, with respect, not particularly illuminating. First, Allan J never gave a definition of "plaintiff culpability". Secondly, the issue of where to consider culpability remains unresolved, because ultimately, his Honour said that culpability could be considered under any component of the tort. These two issues will be dealt with in turn.

\section{A Scope of Plaintiff Culpability}

Plaintiff culpability, as the name implies, entails some kind of "bad" behaviour. Allan J used the terms "culpability", "blameworthiness", and "iniquity" in his discussion of plaintiff culpability. ${ }^{13}$

11 Ibid, para 91 Allan J.

12 Ibid, paras 42-47 Allan J. 
These words have connotations of behaviour that deserves punishment or that should not be protected. When applied to an invasion of privacy claim, the terms suggest that the plaintiff brought the publicity upon him or herself, or was at least partly responsible for, or deserved, the publicity. On one hand, the Andrews were simply unlucky that the fire fighters attending their accident happened to be followed by a television crew. However, on the other hand, they were not the victims of another driver's negligence, but instead were well over the legal alcohol limit and were the authors of their own misfortune. ${ }^{14}$ On this view, the plaintiffs had brought the publicity upon themselves.

However, what about behaviour that is "bad", but which is not behaviour that could be described as "asking for" publicity? Bad behaviour, after all, could still be described as "blameworthy" behaviour. Take the example of a person who cheated on her husband. Broadly speaking, extramarital affairs are still generally considered "bad" behaviour. Nevertheless, if the husband wished to publish details of the affair in a newspaper, the wife could hardly be said to have brought the publicity upon herself. Thus, at least from Allan J's discussion, the wife's bad behaviour would not qualify as culpable behaviour. So, it is necessary to determine the kind of bad behaviour that is relevant in an invasion of privacy case: is it any kind of bad behaviour or is it behaviour where the plaintiff was instrumental in creating the publicity?

Further guidance can be sought from how the New Zealand and English courts have dealt with bad behaviour in invasion of privacy cases. The United Kingdom does not have a tort of invasion of privacy; invasion of privacy claims are brought under the tort of breach of confidence. However, when an action for breach of confidence is brought in respect of a privacy claim, the requirements of the tort are similar to those under the New Zealand tort of invasion of privacy. ${ }^{15}$ Most of the New Zealand cases have not expressly discussed the issue of the plaintiff's bad behaviour, but in some cases an inference can be drawn about how the courts have treated it. The English cases, on the other hand, have been more explicit in their treatment of "bad" plaintiffs.

\section{B Types of Plaintiffs}

At this point, it is necessary to draw a distinction between public and non-public figures, and further, between voluntary and involuntary public figures. These distinctions are important in the area of privacy, because the level of privacy attaching to each type of plaintiff differs. A voluntary public figure has been described as: ${ }^{16}$

13 Ibid, paras 42-43, 46 Allan J.

14 See ibid, para 77 Allan J.

15 For further information about the English breach of confidence action, see for example, Helen Fenwick and Gavin Phillipson Media Freedom under the Human Rights Act (Oxford University Press, New York, 2006) ch 14; Tugendhat and Christie, above $\mathrm{n} 2$, ch 6.

16 Prosser, above n 1, 410. 
a person who, by his accomplishments, fame, or mode of living, or by adopting a profession or calling which gives the public a legitimate public interest in his doings, his affairs, and his character, has become a "public personage".

Involuntary public figures, on the other hand, are essentially ordinary members of society (that is, non-public figures) that have, through some event or other occurrence, been placed in the public spotlight. They have been described as: ${ }^{17}$

individuals who have not sought publicity or consented to it, but through their own conduct or otherwise have become a legitimate subject of public interest. They have, in other words, become "news".

The distinctions between these plaintiffs impact upon what constitutes culpable behaviour for each type of plaintiff; so the facts that constitute culpable behaviour will differ, depending on the type of plaintiff involved. However, the reasons underpinning why the behaviour is culpable are the same. In other words, the reason why certain behaviour is culpable is the same regardless of the type of individual that is concerned.

\section{Voluntary Public Figures}

The kind of bad behaviour that is relevant in public figure cases often involves hypocrisy. The English courts are more experienced than the New Zealand courts in the area of privacy claims brought by public figures, and in particular, celebrities. ${ }^{18}$ The English courts have not been sympathetic towards hypocritical public figures. Hypocrisy is the situation where the public figure has presented a certain image that is favourable towards his or her career, but then acts in a contradictory manner. In other words, the public figure has presented a false image to the public.

The case of Woodward $v$ Hutchins ${ }^{19}$ illustrates the concept of hypocrisy. The case concerned a well-known group of singers. The defendant was the group's press relations agent who, after the termination of his employment with the group, began writing stories for a newspaper about the lives of the members of the group. Lord Denning MR, in discharging the interim injunction granted to the group, stated that: ${ }^{20}$

There is no doubt whatever that this pop group sought publicity. They wanted to have themselves presented to the public in a favourable light so that audiences would come to hear them and support them. ... If a group of this kind seek publicity which is to their advantage, it seems to me that they

17 American Law Institute Restatement of Torts (2 ed, St Paul, Minnesota, 1971) §652 D.

18 See for example, A v B [2003] QB 195 (CA); Campbell v MGN Ltd [2004] 2 AC 457 (HL(E)); McKennitt v Ash [2007] 3 WLR 194 (CA); Theakston v MGN Ltd [2002] EWHC 137; Woodward v Hutchins [1977] 1 WLR 760 (CA).

19 Woodward $v$ Hutchins, ibid.

20 Ibid, 763 Lord Denning MR. 
cannot complain if a servant or employee of theirs afterwards discloses the truth about them. If the image which they fostered was not a true image, it is in the public interest that it should be corrected. ... The public should not be misled.

Thus, the behaviour that the court considered was relevant to the group's invasion of privacy claim was the fact that the group had presented a false image: this was more than just the bad behaviour of the singers behind closed doors. The public figures brought the publicity upon themselves by presenting a false image and running the risk that the truth would be exposed.

A similar situation was seen in Campbell $v$ MGN $L t d,{ }^{21}$ which concerned an internationally famous supermodel. Naomi Campbell had made numerous announcements to the media that she was drug-free, but was subsequently photographed leaving Narcotics Anonymous. Because Campbell had misled the public, the media had a right to set the record straight in respect of her drug addiction and the fact that she was receiving treatment. The House of Lords, however, acknowledged that had she not purported to be drug-free, she would have been entitled to privacy in respect of the information concerning her drug addiction. ${ }^{22}$ This observation suggests that bad behaviour, in this case, drug use, is not on its own enough to impact on an invasion of privacy claim or to deny privacy; ${ }^{23}$ the plaintiff's hypocrisy was determinative.

The situation was slightly different in Theakston $v$ MGN Ltd. ${ }^{24}$ The claimant was a television presenter on a programme aimed at younger audiences. After a night out drinking with friends, he entered a brothel and, according to the prostitutes, left without paying. After refusing their demands to pay, one of the prostitutes sold the story and accompanying photographs to the defendant's newspaper. The hypocrisy in Theakston's behaviour arose from two factors. First, Theakston had often spoken to the media about his private life and who he had intimate relationships with, or at least did not complain when it was published. Thus, to complain about the brothel story was hypocritical. Secondly, Theakston was a role model for his younger audiences. Even though he was not deliberately presented as a role model, Theakston was aware of his position and influence. On this view, Theakston's hypocrisy was similar to Campbell's case. The hypocrisy in Theakston's claim was relevant to the court's decision to refuse to grant an injunction in respect of the story.

In the cases discussed, the public figures acted "badly" in the sense that the behaviour that they were trying to protect was, in itself, bad. For example, taking drugs is bad behaviour. However, they were also "bad" in the sense that they had presented false images to, or had misled, the public, ${ }^{25}$

21 Campbell $v$ MGN Ltd, above n 18.

22 See for example, ibid, para 82 Lord Hope.

23 See also, $C C \vee A B$ [2006] EWHC 3083, para 30 Eady J.

24 Theakston $v$ MGN Ltd, above n 18. See also, $A v B$, above $\mathrm{n} 18$.

25 But see, McKennitt $v$ Ash, above n 18, paras 67-77 Buxton LJ. 
which was what brought about the publicity. If they did not present a false image then the media, arguably, would not have had as great a motive or justification to publish the truth. The relevant "bad" behaviour in the public figure cases has been the behaviour in the second sense, that is, there must be something more than just bad behaviour. Thus, the public figure cases support the view that culpable behaviour requires bad behaviour in the sense that the public figures brought the publicity upon themselves. So, the type of culpable behaviour in cases involving public figures is the same kind of culpable behaviour referred to by Allan J in Andrews $v$ TVNZ.

\section{Involuntary Public Figures and Non-Public Figures}

In contrast to public figures, there is limited case law involving involuntary public figures and non-public figures. Nevertheless, the few decided cases suggest that culpability among these types of plaintiffs also requires an element of responsibility in the plaintiffs for the publicity.

A common example of when involuntary public figures seek the protection of the tort of invasion of privacy is people with criminal convictions who wish to prevent the disclosure of those facts to the public. ${ }^{26}$ In one sense, the criminal convictions are already a matter of public record and are therefore public facts. Also, these aspects of privacy, or the lack of privacy, are created by statute and is beyond the realm of the tort. However, where the publicity moves beyond the function of statute the tort may become relevant.

For example, in Tucker $v$ News Media Ownership Ltd the plaintiff, who had been convicted of indecent assault upon boys a few years earlier, carried out a public fundraising campaign to raise money for a heart transplant. ${ }^{27}$ The media discovered and wished to publish the details of his convictions. Tucker sought an injunction on the basis that publication would be an invasion of his privacy. It was implicitly accepted that the convictions, though once public, had become private again through the passage of time, ${ }^{28}$ which triggered the application of the tort.

The court did not discuss whether Tucker's bad behaviour was relevant. While Tucker's convictions constituted bad behaviour in itself, did he bring the publicity upon himself? In the context of Tucker's public appeal, the court felt that he had brought the publicity upon himself, in the sense that he put himself and his character forward to the public. In other words, Tucker had become an involuntary public figure. However, in terms of whether Tucker was culpable, it could be argued that the fact that his past behaviour had been bad was not relevant to his claim, because it was merely bad behaviour. While his convictions initially brought about publicity through becoming a matter of public record, they had reverted to being private facts and could not be said to have

26 See Tucker v News Media Ownership Ltd [1986] 2 NZLR 716 (HC); Brown v Attorney-General [2006] DCR 630 (DC).

27 Tucker v News Media Ownership, ibid.

28 See also, Brown v Attorney-General, above n 26, para 62 Judge Spear. 
brought about the widespread media publicity several years later. Rather, it was Tucker's public appeal for donations that brought about the publicity, as opposed to his bad behaviour alone. On this view, Tucker was not culpable and therefore his bad behaviour in itself was not a relevant consideration.

In contrast, non-public figures do not act in a way that warrants widespread, or any, publicity about them, and as such there is unlikely to be any public interest in publicity about them. They might act "badly", but without more, they do not bring publicity upon themselves. For example, in $C C \vee A B$ the claimant had an affair with the defendant's wife, which the defendant sought to have published in a newspaper. ${ }^{29}$ The claimant had a "public persona", but was not a public figure. He had not misled the public, nor had he moralised publicly on family life or his own sexual continence. $^{30}$ Thus, he had not brought the publicity upon himself, and the fact that his behaviour was bad did not affect his invasion of privacy claim. ${ }^{31}$ As culpability requires an element of public interest in bad behaviour to drive the publicity, non-public figures are unlikely to be culpable in invasion of privacy cases. ${ }^{32}$

\section{E Conclusion: Plaintiff Culpability}

The cases support the view that plaintiff culpability requires more than merely bad behaviour; it requires an element of fault in the plaintiffs, or that the plaintiffs brought the publicity upon themselves. In other words, culpability refers to bad behaviour where the plaintiff is in some way responsible for the publicity, or at least ran the risk of the publicity occurring. It is not necessarily the bad behaviour itself that is culpable, as illustrated by the public figure cases. For example, in Campbell $v$ MGN Ltd the plaintiff's culpability did not arise from the fact that she had taken drugs alone, but that she had earlier lied about not taking drugs. In Andrews v TVNZ, on the other hand, the bad behaviour, namely driving while drunk, was culpable in itself, because the plaintiffs ran the risk of having an accident and creating the publicity.

Having an element of fault in plaintiff culpability in privacy cases is consistent with the underlying purpose of having the protection of a right to privacy. Having a right to privacy is to enable people to behave differently in a private context than the manner in which they would act or behave in a public setting. ${ }^{33}$ For example, "a person may speak totally properly in public but may

$29 C C \vee A B$, above n 23 .

30 Ibid, para 52 Eady J.

31 Ibid, para 30 Eady J.

32 See also, $L v G$ [2002] DCR 234 (DC): the defendant had taken photographs of the plaintiff's genital area and had them published in an adult lifestyle magazine. Although prostitution might be considered bad behaviour, the plaintiff could not be described as having brought the publicity upon herself and thus was not culpable.

33 Ibid, 248 Abbot J. 
swear volubly in private", yet the person is entitled to do both without the risk of public disclosure of the private use of bad language. ${ }^{34}$ The right to privacy is necessary to protect individual liberty and autonomy to act in private in a way that they would not in public for fear of public disapproval. ${ }^{35}$ But if the plaintiff's bad behaviour has brought about the publicity, the bad behaviour could affect the plaintiff's right to privacy, because the public's interest has been engaged. Whether that interest is legitimate or otherwise is a different issue.

Even if a culpable plaintiff could be described as "deserving" the publicity, it does not necessarily mean that the media is justified in its publication. Plaintiff culpability does not act as a waiver of privacy or consent to publicity. ${ }^{36}$ However, culpability nevertheless should still be a consideration under the tort, as it operates in a manner similar to the defence of iniquity under the breach of confidence tort.

\section{PLAINTIFF CULPABILITY AND INIQUITY}

Allan $\mathrm{J}$ compared culpability to the iniquity defence in the English breach of confidence claims. ${ }^{37}$ The iniquity defence follows the equitable maxim "he or she who comes into equity must come with clean hands." ${ }^{38}$ The defence operates such that if the court considers that the plaintiff's personal conduct in respect of the information has been improper, then the court is entitled to refuse relief. ${ }^{39}$ In other words, equity will not protect claimants who, themselves, have also done something wrong or bad. So the defence of iniquity is concerned with fairness. In drawing the comparison, plaintiff culpability is relevant to an invasion of privacy claim because it might not be fair to allow plaintiffs to rely on their privacy rights to prevent publicity relating to their culpable behaviour, especially if they created the publicity. Thus, the relevance of culpability is also concerned with notions of fairness, rather than with punishing the plaintiff for his or her bad behaviour. If the plaintiffs brought the publicity upon themselves then they should not necessarily be able to hide behind the tort of invasion of privacy.

However, while culpability might in some circumstances give the public a right to be informed about the behaviour, some might not agree that the public should be informed, and so perhaps culpability should not affect the tort. One commentator has said that "it is unclear how the public

34 Ibid.

35 See Charles Fried "Privacy" (1968) 77 Yale LJ 475, 483; Gavison, above n 2, 448.

36 See Andrews v TVNZ, above n 7, para 78 Allan J.

37 See for example, Lion Laboratories v Evans and Others [1984] 3 WLR 539 (CA).

38 See generally Patricia Loughlan "The Historical Role of the Equitable Jurisdiction" in Patrick Parkinson (ed) Principles of Equity (LBC Information Services, Sydney, 1996) 3, 26.

39 Rebecca Taseff "Available Defences: the NZ Privacy Tort and the UK's Extended Action for Breach of Confidence" (2006) 2(10) Priv LB 141, 142. 
interest is harmed by people labouring under incorrect impressions about the private lives of celebrities." 40 Further, "if the concern is the moral damage to those influenced by role models, then surely publication of the information is central to causing such damage." 41 The commentator appeared to be suggesting that the public interest might be better served by not informing the public that they had been misled by celebrities. With respect, it should not be assumed that it is in the public's interest to allow them to be misled by celebrities; it would not be fair for celebrities to gain from misleading the public.

The culpability of the plaintiff should be taken into account in an invasion of privacy claim as it is relevant to determining whether the plaintiff deserves the protection of the tort. Culpability should impact on the tort in a way similar to the defence of iniquity in a breach of confidence action. In terms of how culpability is taken into account, it could affect a plaintiff's reasonable expectations of privacy, the highly offensive test, or the public interest defence. ${ }^{42}$ Allan J, however, made several references to the impact of plaintiff culpability on reasonable expectations of privacy, ${ }^{43}$ which suggests that he felt it was under the first limb that culpability should be considered.

\section{REASONABLE EXPECTATIONS OF PRIVACY}

In Andrews $v$ TVNZ, the communications between the plaintiffs were described as being of an "intimate character and of an altogether more personal nature than the information with which Hosking $v$ Runting was concerned." 44 The plaintiffs were held to have had a legitimate expectation that there would be no additional publicity given to the conversations. ${ }^{45}$ Allan $\mathrm{J}$ reached this conclusion without discussing the impact of the plaintiffs' culpable behaviour. Nevertheless, should culpability have been considered under the reasonable expectations of privacy test?

\section{A The Test of Reasonable Expectations of Privacy}

Under the first limb of the tort of invasion of privacy, the test is whether there are facts in respect of which there is a reasonable expectation of privacy. ${ }^{46}$ There is no simple test to determine

40 Tanya Aplin "The Development of the Action for Breach of Confidence in a Post-HRA Era" (2007) 1 IPQ 19, 45. See also, Fenwick and Phillipson, above n 15, 786-805.

41 Aplin, ibid, 45.

42 Andrews v TVNZ, above n 7, para 47 Allan $\mathrm{J}$.

43 Ibid, paras 42-47 Allan J.

44 Ibid, para 65 Allan J.

45 Ibid, para 85 Allan J. It should be noted that the accident occurred in a public place, where there generally can be no reasonable expectation of privacy. Discussion about this issue is beyond the scope of this article, but for further discussion see Hosking v Runting, above n 4, para 164 Gault P and Blanchard J; Nicole Moreham "Privacy in Public Places" [2006] NZLJ 265.

46 Hosking $v$ Runting, above n 4, para 117 Gault P and Blanchard J. 
what constitutes a private fact. ${ }^{47}$ Private facts have been described as "those that may be known to some people, but not to the world at large." 48 Essentially, the inquiry into whether facts are private in nature involves an assessment as to whether there is a reasonable expectation of privacy in respect of that information. ${ }^{49}$

The level of a reasonable expectation of privacy differs according to the individual involved. ${ }^{50}$ For example, voluntary public figures will have lower expectations of privacy than involuntary public figures, who will also experience a lessening of expectations of privacy. ${ }^{51}$ Non-public figures have the highest expectations of privacy. Despite the differences, the question remains the same: should plaintiff culpability reduce an individual's expectations of privacy?

\section{B Allan J's Suggestions}

Allan J said that plaintiff culpability could affect the "reasonableness" of an expectation of privacy, ${ }^{52}$ which suggests that the greater the gravity of culpability, the less reasonable an expectation of privacy becomes. Allan $\mathrm{J}$ also said that "an expectation of privacy, otherwise reasonable, may in certain circumstances be lost by reason of culpability on the part of the plaintiff". ${ }^{53}$ This statement implies that even if the plaintiff had a legitimate expectation of privacy, the expectation could be denied by virtue of the culpability. Essentially, Allan J was saying that plaintiff culpability could lead to a failure of the reasonable expectations of privacy test.

\section{Impact of Plaintiff Culpability on Reasonable Expectations of Privacy}

The reasonable expectations of privacy test is considered from the perspective of an objective reasonable person, which prima facie does not include considerations of culpability. The case of Brown $v$ Attorney-General illustrates this point. ${ }^{54}$ In that case, the plaintiff was a convicted paedophile. The police, concerned at the plaintiff's risk of re-offending, printed and distributed fliers containing detailed information about the plaintiff to the neighbourhood where he was living. It

47 Ibid, para 119 Gault P and Blanchard J. For further information about the reasonable expectations of privacy test, see Stephen Todd (ed) The Law of Torts in New Zealand (4 ed, Brookers Ltd, Wellington, 2005) 756759.

48 Hosking $v$ Runting, ibid, para 119 Gault P and Blanchard J.

49 Ibid, para 117 Gault P and Blanchard J. See also, Rogers v TVNZ (CA), above n 6, para 51 Panckhurst and O'Regan JJ.

50 Hosking $v$ Runting, ibid, para 121 Gault $\mathrm{P}$ and Blanchard J. See also $A v B$, above n 18, para 11 point (xii) Lord Woolf CJ for the Court.

51 Hosking v Runting, above n 4, para 121 Gault P and Blanchard J.

52 Andrews v TVNZ, above n 7, para 42 Allan J.

53 Ibid, para 47 Allan J.

54 Brown v Attorney-General, above n 26. 
included the plaintiff's name, address, details of his convictions, and also a photograph of him. Judge Spear said that the test is whether an objective observer, as opposed to a convicted paedophile, would have a reasonable expectation of privacy, taking into account the surrounding circumstances. ${ }^{55}$

The "surrounding circumstances" refers to the situation in which the facts were brought into existence, ${ }^{56}$ such as whether the facts were imparted in a public place or a private home. Could the surrounding circumstances include the plaintiff's culpability? In interpreting Judge Spear's application of the test, the distinction between merely bad behaviour and culpable behaviour becomes important. Judge Spear's test suggests that merely bad behaviour, without more, is not relevant to the reasonable expectations of privacy test. However, it is possible that the surrounding circumstances include the plaintiff's culpability.

If culpable plaintiffs play a part in bringing about the publicity, it is arguable that the culpability would form part of the surrounding circumstances. The plaintiffs, by virtue of their culpable behaviour, create the situation or engage in behaviour where they can expect greater media interest. In that situation it becomes less reasonable for them to have as high an expectation of privacy than they would have had, had they not behaved culpably. This lessening of expectations of privacy is similar to that of public figures who, because they choose to put a part of their lives in the public spotlight, bring the publicity upon themselves, and as a result have reduced expectations of privacy.

The analogy between culpable plaintiffs and public figures should not, however, be drawn too far. Often, in the case of public figures, personal information about them has been so widely published that that information or type of information has become a part of the public domain. In contrast, the argument that culpable plaintiffs have reduced expectations of privacy is based on the premise that a reasonable person in their position would realise that there is a level of public interest in their behaviour, because they created it themselves. Accordingly, the argument would be that this knowledge should reduce a person's expectations of privacy. There may be some overlap between the two categories in cases involving culpable public figures. ${ }^{57}$

In other words, a culpable plaintiff's reduced expectations of privacy are fuelled by the public interest, and the plaintiff's awareness of that public interest, in their actions. It follows that, in determining whether a plaintiff passes limb one, a court would have to consider whether the level of public interest in the information is sufficient to deny a plaintiff his or her expectations of privacy. That is, would a reasonable person, knowing that they had created the public interest in their actions,

55 Ibid, paras 71-72 Judge Spear. See also, Television New Zealand v Rogers, above n 6, para 50 Panckhurst and O'Regan JJ.

56 Brown v Attorney-General, ibid.

57 For example, see Campbell v MGN Ltd, above n 18; Theakston v MGN Ltd, above $\mathrm{n} 18$. 
expect the information to be private? This analysis begins to complicate the first limb of the invasion of privacy test.

The purpose of considering public interest under the first limb would be to recognise that where a culpable plaintiff has engaged in behaviour that is of legitimate public concern, he or she cannot expect the information to remain private. The problem with this analysis is that the public interest in a particular case requires independent consideration, which is why it is a separate defence to the tort. ${ }^{58}$ Considering culpability under limb one would essentially combine what should be two tests into one. This result would be undesirable, particularly since the aim in doing so could also be achieved by considering culpability under the public interest defence. Thus, although the reasonable expectations of privacy test is wide enough to consider culpability, it would be better to consider culpability under the public interest defence.

\section{THE "HIGHLY OFFENSIVE" TEST}

Before the public interest defence is analysed, the highly offensive test will be discussed. The highly offensive test is the second fundamental requirement for a successful claim under the tort of invasion of privacy. ${ }^{59}$ The court must be satisfied that an objective reasonable person in the shoes of the plaintiff would find the publicity given to the private facts to be highly offensive. ${ }^{60}$ The focus is on whether the publicity is highly offensive and not on whether the facts are private. ${ }^{61}$ The test is concerned with publicity that is truly humiliating and distressful or otherwise harmful to the individual concerned; economic loss or personal injury is not necessary. ${ }^{62}$

By this stage, the facts would have already been proven to be private. If the facts were private it would usually follow that publicity given to them would be highly offensive to a reasonable person. But that is not always the case, as seen in Andrews $v$ TVNZ. Essentially, the tort is not intended to protect private facts that are not sensitive, and thus any publicity given to those facts would not be highly offensive to a reasonable person.

\section{A The Test as Applied in Andrews v TVNZ}

In the light of the observations above, one would think that the plaintiffs in Andrews $v$ TVNZ would have succeeded under the highly offensive test, as their conversations were held to have been of an intimate and personal nature. However, the plaintiffs failed. Allan J found that neither plaintiff

58

59

60 ibid, para 67 Panckhurst and O'Regan JJ. For further information about the highly offensive test, see Todd,
above n 47, 759-762.

61 Hosking v Runting, above n 4, para 127 Gault P and Blanchard J.

62 Ibid, para 128 Gault P and Blanchard J.

Hosking v Runting, above n 4, para 129 Gault P and Blanchard J.

But see, Rogers v Television New Zealand Limited, above n 6, para 25 Elias CJ.

osking v Runting, above n 4, para 117 Gault P and Blanchard J. See also Rogers v Television New Zealand, 
could "point to anything" in the programme that was embarrassing or that showed them in a bad light, ${ }^{63}$ and implied that the conversations were "not really sensitive". ${ }^{64}$ His Honour said that the heart of the plaintiffs' complaint was that their consent was not obtained during the production of the programme. ${ }^{65}$ These factors combined led his Honour to the conclusion that the publicity was not humiliating or distressful.

Allan J's analysis of the test is, with respect, questionable. First, it is contradictory to conclude that the intimate and personal conversations were anything other than sensitive. Secondly, Allan J was, in essence, equating "embarrassing" with "humiliating or distressful". The fact that someone is not embarrassed by the publicity does not necessarily mean that the publicity is not humiliating, distressful, or otherwise harmful. Embarrassment invokes feelings of self-consciousness, whereas humiliation and distress invoke feelings of pain or anxiety. Even if Mrs Andrews was not embarrassed by the publicity, a reasonable person in her shoes would still have been distressed to relive the moments where her husband was being cut out of a car wreckage, with the knowledge that it was being broadcast nationally.

\section{B Plaintiff Culpability and the Highly Offensive Test}

Allan $\mathrm{J}$ did not appear to have much sympathy for the Andrews. It is likely that a reasonable person in the shoes of the plaintiffs would have found the publicity to be highly offensive. So why did Allan J decide that the plaintiffs failed the test? It is possible that his Honour felt that because of the plaintiffs' culpability, they should not have been highly offended at the publicity. ${ }^{66}$

In Campbell v MGN Ltd Lord Hope said that the highly offensive test requires placing oneself into the shoes of a reasonable person who is in need of treatment for drug addiction. ${ }^{67}$ In other words, the reasonable person has the sensibilities of a recovering drug addict. Lord Hope, however, made no reference to Campbell's culpable behaviour in respect of its impact on the highly offensive test. That omission was perhaps deliberate. As a recovering drug addict, even if Campbell had brought the publicity upon herself by lying about not taking drugs, that does not mean that a

63 Andrews $v$ TVNZ, above $\mathrm{n} 7$, paras 67-68 Allan J.

64 Ibid, para 71 Allan J.

65 Ibid, para 69 Allan J.

66 Ibid, para 67 Allan J. For example, his Honour referred to the fact that the programme did not mention the plaintiffs' excess blood alcohol level. He also placed heavy weight on the failure of either plaintiff to point to anything embarrassing or that showed them in a bad light in the programme, which seemed to be the basis of the failure under the highly offensive test. These factors suggest that Allan J thought that the situation for the plaintiffs could have been worse, and thus, perhaps, that the plaintiffs should not have been highly offended.

67 Campbell $v$ MGN Ltd, above n 18, para 98 Lord Hope. See also, P v D [2000] 2 NZLR 591 (HC), para 39 Nicholson $\mathrm{J}$. 
reasonable person in her shoes would have found the publicity to be any less humiliating or distressful. Similarly, even though the Andrews ran the risk of publicity by driving while drunk, it does not somehow make the reasonable person in their shoes more immune to viewing the footage of the rescue scene.

Thus, whether Allan $\mathrm{J}$ did or did not take culpability into account, culpability is not an appropriate factor to consider under the highly offensive test. Culpability does not give a reasonable person greater immunity that renders them less likely to be humiliated or distressed at publicity given to private facts. Culpability appears to be a rather artificial reason to fail the highly offensive test and it should not be a relevant consideration under this limb.

\section{THE PUBLIC INTEREST DEFENCE}

The analysis thus far has pointed towards the conclusion that culpable behaviour should be considered under the public interest defence. ${ }^{68}$ In Hosking $v$ Runting, the public interest was confirmed to be a defence to the tort, rather than being an element within it. ${ }^{69}$ The tort must recognise that a person's desire for privacy must sometimes give way to the public interest in publishing certain facts or information. ${ }^{70}$ Matters of general interest or curiosity to the public, however, will not satisfy the public interest defence; there must be a legitimate public concern in the publication. The public interest defence should ensure that an individual could not use a privacy action to hide his or her culpability, ${ }^{71}$ but the level of legitimate public concern must be of sufficient gravity to outweigh the level of harm that is likely to be caused by the invasion of privacy. ${ }^{72}$

\section{A Voluntary Public Figures}

Voluntary public figures, by placing their characters in the public eye, invite a certain degree of examination by the public into their backgrounds and lives. Therefore, there is a higher level of public interest in them than there is in an ordinary person. In $A v B$, Lord Woolf CJ said that in many situations it would be overstating the position to say that there is public interest in the information being published. ${ }^{73}$ However, his Lordship said that in these situations the public have an

68 For further information about the public interest defence, see Todd, above $n$ 47, 762-764; Tugendhat and Christie, above n 2, 349-372.

69 Hosking $v$ Runting, above $\mathrm{n}$ 4, para 129 Gault $\mathrm{P}$ and Blanchard J. Contrast $P$ v D, above $\mathrm{n}$ 67, para 34 Nicholson J.

70 Moreham "Privacy in the Common Law", above n 1, 644.

71 See ibid.

72 Hosking $v$ Runting, above n 4, para 134 Gault P and Blanchard J.

$73 A v B$, above n 18, para 11 point (xii) Lord Woolf CJ for the Court. 
"understandable and so a legitimate interest in being told the information." ${ }^{74}$ These comments suggest that the publication of private facts could be justified simply because they relate to a public figure.

However, the Court of Appeal in Campbell v MGN Ltd said that just because a person has achieved prominence on the public stage it does not mean that "his private life can be laid bare by the media." 75 Thus, where truly private or sensitive information is concerned, to justify the defence the public interest must go beyond being merely the public's interest in the public figure; the public must have a legitimate right to know.

Where a public figure does something bad, for example, uses drugs, there is a level of public interest in it, simply because it concerns a public figure. However, the level of public interest in the individual on its own would not necessarily outweigh the public figure's right to privacy. The presence of culpability can form the core of a successful public interest defence. This point was illustrated in Campbell v MGN Ltd, ${ }^{76}$ where it was Campbell's hypocrisy that justified publication of the fact of her drug addiction and treatment, not her drug addiction in itself.

Plaintiff culpability can also add strength to a public interest defence. In Theakston v MGN Ltd the claimant had placed aspects of his private life and his general attitude towards sexual relations in the public domain. ${ }^{77}$ It followed that his expectations of privacy were lowered in respect of those matters, and correspondingly, the public interest in them was increased. Theakston's culpability in his hypocrisy strengthened the public interest defence. ${ }^{78}$ One of two reasons for his hypocrisy was that he had an image as a role model. On this point Ouseley J stated that: ${ }^{79}$

the very nature of his job as a TV presenter of programmes for the younger viewer means that he will be seen as somebody whose lifestyle ... is one which does not attract moral opprobrium and would at least be generally harmless if followed .... The activity in question here may make viewers or the parents of viewers react differently.

Thus, the public had a legitimate interest in knowing about Mr Theakston's culpable behaviour, because the public had based their actions on that false image and so they had a right to be told the truth in order to adjust their conduct.

74 Ibid.

75 Campbell v MGN Ltd [2003] QB 633, paras 40-41 (CA) Lord Phillips of Worth Matravers MR, cited in McKennitt $v$ Ash [2007] 3 WLR 194, para 65 (CA) Buxton LJ.

76 Campbell $v$ MGN, above $n 18$.

77 Theakston v MGN Ltd, above n 18, para 68 Ouseley J.

78 Ibid, para 69 Ouseley J.

79 Ibid. 
A similar situation was seen in $A v B .^{80}$ The plaintiff was a well-known footballer who cheated on his wife with a lap dancer. He successfully applied for an interim injunction preventing the newspaper, to which the lap dancer had sold her story, from publishing the details of the affair. The injunction was discharged on appeal. The main reason was that the relationship was not one that should be protected where one party to the relationship wished to publish it. ${ }^{81}$ However, the culpability of the plaintiff's actions was also recognised and discussed under the public interest defence. Lord Woolf CJ stated that "footballers are role models for young people and undesirable behaviour on their part can set an unfortunate example." 82 Again, it was the culpability of the public figure that supported the public interest defence.

It might seem questionable that public figures are treated as having breached their duty to act responsibly when they engage in behaviour such as entering a brothel or having an affair. These activities are legal, and further, in today's society it is arguable that such activities are not still considered to be immoral. ${ }^{83}$ It would not constitute culpable behaviour for a non-public figure, or even an involuntary public figure, to engage in such conduct. Lord Woolf CJ in $A \vee B$ provided an explanation for the law's treatment of such behaviour by public figures: ${ }^{84}$

The public figure may hold a position where higher standards of conduct can be rightly expected by the public. The public figure may be a role model whose conduct could well be emulated by others. He may set the fashion.

Therefore, voluntary public figures are in a different situation to other people, because they are in a position of influence over certain groups of the public, and that carries with it a higher standard of conduct. ${ }^{85}$ Thus, the public might have a legitimate interest in being informed about a public figure's culpability, because of the impact that a false image can have on the public's actions.

$80 \quad A v B$, above n 18.

81 Ibid, para 43 Lord Woolf CJ for the Court.

82 Ibid.

83 See Stephens v Avery and Others [1988] Ch 449, 453 (Ch) Sir Nicolas Browne-Wilkinson V-C.

$84 A \vee B$, above $\mathrm{n} 18$, para 11 point (xii) Lord Woolf CJ for the Court.

85 Some commentators have felt that the English courts have been too lenient in their considerations under the public interest defence and have accepted "flimsy" public interest arguments, with particular reference to celebrities and the "role models should not mislead" argument in Theakston $v$ MGN Ltd and A $v$ B. It is beyond the scope of this article to discuss the matter, but for further discussion, see Aplin, above $n$ 40, 4451 and Fenwick and Phillipson, above n 15, 786-803. 


\section{B Involuntary Public Figures}

The case of Brown $v$ Attorney-General ${ }^{86}$ provides an example of how the New Zealand courts have dealt with culpable behaviour in the context of an involuntary public figure. The police argued that there was a legitimate public interest in informing the residents that a convicted paedophile was living in their neighbourhood, which was to ensure that children were safe. Judge Spear ruled that: ${ }^{87}$

Any legitimate public interest in a convicted and recently paroled paedophile living in the Strathmore community could have been met without releasing such extensive private information about the plaintiff

to such a wide audience.

Thus, there was a legitimate public interest in informing the public that a convicted paedophile was living in the community and it could have outweighed the plaintiff's right to privacy, but the information released was too extensive for the public interest to justify. The court did not say how restricted the information released had to be, but the court at least indicated that it is possible for plaintiff culpability to be considered under the public interest defence.

\section{Conclusion: Public Interest}

The public interest defence lends itself well to considerations of plaintiff culpability. However, whether culpability forms the core of a public interest defence or enhances the defence, overall, the public interest must be of sufficient gravity to outweigh the invasion of privacy. Once it has been determined that the public interest defence does justify the invasion of privacy, it must still be determined how much publicity the public interest justifies.

\section{NEXUS BETWEEN CULPABLE BEHAVIOUR AND THE PUBLIC INTEREST}

There must be a logical nexus between the plaintiff's culpable behaviour and the public interest defence that is raised. ${ }^{88}$ There are limits to the extent of publicity that a successful public interest defence will allow regarding the culpable behaviour. If the reason underlying the consideration of culpability is fairness, then the publicity should go only as far as bringing the culpability to the public's attention.

However, determining what is necessary to satisfy the reasons for publication under the public interest defence is not a straightforward task. For example, in Campbell v MGN Ltd the public interest argument was that Campbell had misled the public and so the media had a right to put the record straight. Thus, on the majority's view, the public interest defence enabled the newspaper to expose the culpability by publishing the fact that Campbell was a drug addict and that she was

86 Brown v Attorney-General, above n 26.

87 Ibid, para 93 Judge Spear.

88 See generally, Tugendhat and Christie, above n 2, 349-372. 
receiving treatment. However, the details about her treatment at Narcotics Anonymous and the accompanying photographs went beyond what was necessary to inform the public of her hypocrisy. ${ }^{89}$ The minority, on the other hand, would have allowed those additional details to be published.

This issue concerns the degree of "journalistic latitude" that is given to the media. ${ }^{90}$ The House of Lords accepted that in relation to the presentation of Campbell's drug addiction, a degree of journalistic latitude was appropriate. ${ }^{91}$ The minority, however, were prepared to stretch the degree of journalistic latitude further than the majority. The minority felt that publishing the details of Campbell's treatment at Narcotics Anonymous and the photographs fell within the degree of journalistic latitude given to the defendants, ${ }^{92}$ whereas the majority felt otherwise. ${ }^{93}$ However, the issue will remain one for the courts to determine in future cases, as it is beyond the scope of the present discussion.

\section{REVISITING ANDREWS V TVNZ}

Returning to Andrews v TVNZ, Mr and Mrs Andrews became involuntary public figures when the rescue team arrived with the television crew in tow at the scene of their car accident. For the reasons discussed earlier, there should have been a finding that there had been an invasion of the Andrews' privacy. ${ }^{94}$

In an obiter dictum, Allan J said that he was prepared to uphold a public interest defence on the basis that the public have a right to be informed about the impact of road accidents on fire fighters and the costs to the public. ${ }^{95}$ However, was the plaintiffs' culpability in driving while drunk also relevant under the public interest defence? At first instance, it appears that culpability could have enhanced the public interest defence. It was most likely that the accident was caused by the driver's excess blood alcohol limit. Considering the high road toll in New Zealand caused by drunk drivers, there is a legitimate public interest in educating the public about the consequences of drinking and driving.

89 See also Brown v Attorney-General, above n 26, para 93 Judge Spear; Theakston v MGN Ltd, above n 18, paras 78-79 Ouseley J.

90 See also, Rogers v Television New Zealand, above n 6, para 128 Panckhurst and O'Regan JJ.

91 For example, see Campbell v MGN Ltd, above n 18, para 112 Lord Hope.

92 Ibid, para 77 Lord Hoffmann.

93 Ibid, para 124 Lord Hope.

94 See Part VI The "Highly Offensive" Test.

95 Andrews $v$ TVNZ, above n 7, para 91 Allan J. 
However, the Andrews were not claiming an invasion of privacy in respect of any publicity concerning their blood alcohol levels, because there was no publicity given to that information; they were instead complaining about the publicity give to their intimate conversations. Could the public interest in the culpability be used to justify the publicity given to the conversations? On the one hand, the conversations were caused by the plaintiffs' culpability, which creates a close nexus between the two and could possibly justify treating the conversations as a manifestation of the culpable behaviour. On the other hand, the public interest in educating the public about the costs of drinking and driving is not achieved by broadcasting the conversations, because the viewers were not told of the plaintiffs' excess blood alcohol levels.

The first approach extends the taint of the culpability, because the culpability would be able to justify publicity given to information that was beyond the culpable behaviour itself. This approach has a greater focus on punishment than the second approach, which focuses on giving effect to the public interest argument. For the following reasons, the second approach should be adopted. First, the reason underlying the relevance of culpability in an invasion of privacy claim is concerned with fairness, rather than on punishing the plaintiff. Secondly, there must be a nexus between the culpable behaviour and the public interest. Had the programme mentioned the plaintiffs' blood alcohol level, plaintiff culpability would have enhanced the public interest. However, the Andrews were not trying to hide their culpability behind the tort, and the footage did not increase viewer awareness of the consequences of driving while drunk. Thus, plaintiff culpability would not have been able to enhance the public interest defence in Andrews $v$ TVNZ. Even though the Andrews' culpability did not affect the outcome of the case, it is still important to give culpability independent consideration in order to create a precedent that can be followed in future cases.

\section{CONCLUSION}

Plaintiff culpability is not a new issue in New Zealand invasion of privacy cases. It has appeared in several cases, but has never had an identity of its own, which has resulted in uncertainty and inconsistency. The confirmation of the tort of invasion of privacy in Hosking $v$ Runting provided an opportunity to start again by building on the basic components of the tort set out by the Court of Appeal.

Using guidance from the case law in New Zealand and the United Kingdom, the following conclusions were reached on plaintiff culpability. First, plaintiff culpability requires more than merely bad behaviour, it requires behaviour where the plaintiff was, at least partly, responsible for the publicity. Secondly, culpability in itself is not determinative of an invasion of privacy claim. The best limb to consider culpability under would be the public interest defence, provided that there is a nexus between the two. Lastly, in Andrews v TVNZ a consideration of plaintiff culpability under the public interest defence would not have helped to justify the publicity, because broadcasting the footage would not have given effect to the public interest argument. That is, the publicity did not go towards educating the public about the consequences of drinking and driving, because the programme did not mention that the driver was drunk. 
While considering plaintiff culpability under the public interest defence would not have changed the outcome of Andrews $v$ TVNZ, it would nevertheless have dealt with culpability in a manner that could be followed in future cases. The conclusions reached in this article enable plaintiff culpability to be applied in future cases in a consistent manner to provide certainty in the tort of invasion of privacy. 